Brit. J. vener. Dis. (1965), 41, 149.

\title{
AORTIC INCOMPETENCE ASSOCIATED WITH CONGENITAL SYPHILIS*
}

\author{
BY \\ R. J. WHITE \\ St. Bartholomew's Hospital, London
}

Congenital syphilis may show any of the manifestations of acquired syphilis, although involvement of the aortic valve is rare. A full review of such cases has been published by Bonugli (1961) and a further case with interesting additional features is described here.

\section{Case Report}

A 22-year-old gardener presented in June, 1964, with symptoms of angina of effort and was found to have aortic incompetence. He had had retrosternal pain on effort for one month and shortness of breath for several months. He also complained of long-standing frequency of micturition, up to every half-hour, and he had had nocturnal enuresis for as long as he could remember. There was no past history of rheumatic fever. His parents were both alive. He had three sisters: one twin, one younger, and one older.

Examination revealed a slightly built man weighing $7 \mathrm{st} .11 \mathrm{lb}$. There were some minor stigmata of congenital syphilis: his upper incisors were slightly wedge-shaped and there was an increased carrying angle at the elbow. The pulse was collapsing in character and the early diastolic murmur of aortic incompetence was present; BP was $140 / 60$. Neurological examination revealed normal pupils, but absent knee, ankle, and supinator jerks.

He was admitted for further investigation and the following results were obtained:

WR positive, titre 1:128.

RPCF positive.

TPI positive.

Urine: no albumin or sugar. Centrifuged deposit normal.

Cerebrospinal fluid: WR and RPCF positive.

Cell count: 4 polymorphs, 24 lymphocytes per c.mm. Protein: $51 \mathrm{mg}$. per $100 \mathrm{ml}$.

Lange gold curve: 2344421000.

ECG: left ventricular "strain".

$X$ rays of chest and tibiae normal.

Audiogram: normal.

Ophthalmological examination showed absence of corneal or retinal abnormality. Cystoscopy showed a normal bladder with no prostatic projection. A mic-

\footnotetext{
* Received for publication January 18, 1965.
}

turating cystogram was normal. No cause, therefore, was found for his long-standing urinary symptoms.

$\mathrm{He}$ was treated with 20 daily injections of procaine penicillin 600,000 units. His weight on discharge was 9 st. (an increase of $17 \mathrm{lb}$.). He was placed on the disabled persons register and arrangements were made for his rehabilitation as a clerk.

His family were investigated with the following results:

Father: WR and RPCF negative; he denied previous infection.

Mother: WR positive, RPCF negative; she stated that she was treated for late syphilis in 1951.

Older sister: WR negative, RPCF negative.

Twin sister: WR negative, RPCF positive. She contracted gonorrhoea at the age of 16 and was treated for syphilis at this time because the STS were found to be positive.

Younger sister: WR and RPCF negative.

\section{Discussion}

It seems highly likely that this patient's syphilis was congenital in origin. In view of the absence of left ventricular hypertrophy it was thought likely that the angina was due to coronary ostial narrowing rather than to aortic regurgitation. It cannot be proved that the valve lesion was syphilitic in origin, but the absence of a history of rheumatic fever, while not excluding this as the cause, does suggest a syphilitic aetiology. It is interesting to note that the patient also had neurosyphilis.

\section{Summary}

A patient with congenital syphilis with cardiovascular and neurological involvement is described.

I would like to thank Dr C. S. Nicol for his help and advice.

\section{REFERENCE}

Bonugli, F. S. (1961), Brit.J. vener. Dis., 37, 257.

Insuffisance aortique associée à une syphilis congénitale RÉSUMÉ

On rapporte l'observation d'un patient atteint de syphilis congénitale avec atteinte cardiaque et nerveuse, 